\title{
Article \\ Environmental Orientation and Green Competitive Advantage of Hospitality Firms in South Africa: Mediating Effect of Green Innovation
}

\author{
Olawale Fatoki (iD
}

Citation: Fatoki, O. Environmental Orientation and Green Competitive Advantage of Hospitality Firms in South Africa: Mediating Effect of Green Innovation. J. Open Innov.

Technol. Mark. Complex. 2021, 7, 223. https://doi.org/10.3390/ joitmc7040223

Received: 4 August 2021

Accepted: 11 October 2021

Published: 8 November 2021

Publisher's Note: MDPI stays neutral with regard to jurisdictional claims in published maps and institutional affiliations.

Copyright: (C) 2021 by the author. Licensee MDPI, Basel, Switzerland. This article is an open access article distributed under the terms and conditions of the Creative Commons Attribution (CC BY) license (https:/ / creativecommons.org/licenses/by/ $4.0 /)$.
Department of Business Management, University of Limpopo, Sovenga 0727, South Africa; olawale.fatoki@ul.ac.za

\begin{abstract}
The hospitality industry exerts significant pressure on the environment through the consumption of resources such as energy and water. However, the industry can also enhance environmental preservation through their operation and strategy. This study examined whether environmental orientation (internal and external) and green competitive advantage are significantly positively related. This study also investigated the indirect effect of green innovation. A quantitative research method was used for this study. The cross-sectional survey method was used as the method of data collection. This study used Partial Least Square Structural Equation modelling to test the hypotheses. The findings showed that environmental orientation and green competitive advantage are significantly positively related. The indirect effect of green innovation is significant. Theoretically, the study developed a model that linked green innovation to environmental orientation. Practically, the study suggests some recommendations on how the managers of hospitality firms can improve environmental orientation. These include the provision of training and development workshops on environmental strategy for management and employees.
\end{abstract}

Keywords: internal environmental orientation; external environmental orientation; green competitive advantage; green innovation; hospitality business; South Africa

\section{Introduction}

Environmental challenges such as global warming, pollution, loss of biodiversity, natural resource depletion, ozone layer depletion, deforestation, and waste disposal have become globally recognised problems [1,2]. Business and human activities are central to the debate on global environmental challenges [3]. The hospitality industry is a major economic sector in most countries with significant contribution to employment and economic growth [4]. However, the hospitality industry also negatively affects the environment through over consumption of natural resources, pollution, and solid and liquid waste $[5,6]$. Despite the fact that businesses contribute significantly to environmental degradation, they can also enhance environmental preservation through their activities $[7,8]$.

Nowadays, there is immense pressure on business to practice sustainability and environmental orientation. The pressure has come from government environmental rules and regulations, international environmental agreements, industry environmental management practices, and consumer pro-environmental behaviour [9-11]. Hotels in particular should be in interested in greening, as this can help to improve image and reputation, attract green customers, reduce costs, obtain environmental accreditations, and meet government environmental regulations [12].

Corporate environmental orientation describes the responsibility of business towards the environment. It refers to the importance of the recognition of the effect that a firm has on the environment and the need to minimise such effect [8]. Environmental orientation (EO) can be divided into two parts: internal and external environmental orientation. Internal environmental orientation (IEO) is focused on a firm's internal values and commitment to 
environmental protection. External environmental orientation (EEO) depicts the perception of the managers of a firm about the environmental needs of external stakeholders and the importance of responding to the interests of external stakeholders [9-11]. EO is beneficial to a firm in many ways. It can lead to cost savings, better brand reputation, increased demand, customer attraction and retention, employee attraction and retention, and improved environmental and financial performance $[13,14]$. However, another stream of research argues that the adoption of EO increases the cost of operation, does not produce significant cost savings, and does not significantly impact on firm financial performance [15,16].

Chen and Chang and Astuti and Datrini $[16,17]$ suggest that the conflict between environmental management and firm performance can be resolved with green competitive advantage (GCA). Astuti and Datrini [17] argue that "green competitive advantages provide [a] win-win solution for the conflict between environmental management and corporate performance" (p. 530). GCA is defined as a situation by which a firm occupies certain positions about environmental management that competitors find difficult to copy, and the firm is thus able to gain the benefits of successful environmental strategies [17]. Therefore, it is important to examine the relationship between EO and GCA.

Empirical studies have tended to focus on the direct relationship between $\mathrm{EO}$ and firm performance $[18,19]$. However, recently, the indirect relationship between $\mathrm{EO}$ and firm performance has become a new line of inquiry [10,20]. Therefore, the development of new theoretical models that consider variables that can mediate the effect of $\mathrm{EO}$ and firm performance will be a significant addition to knowledge $[10,20]$. This study draws on green innovation as a mediating variable in the relationship between EO and GCA. Green innovation can be described as innovations that help to reduce waste, prevent pollution, and improve the environmental performance of a firm [21]. Thus, GI may help to reduce a firm's negative impact on natural environment, meet customer needs, fulfil stakeholder expectations, and positively impact on competitive advantage [22]. This study has two objectives: (1) to investigate the relationship between EO (IEO and EEO) and GCA and (2) to investigate if GI indirectly affects the relationship between EO and GCA.

The study will contribute to knowledge in the following ways. First, research on the EO-firm performance nexus has tended to focus on financial performance with conflicting results. However, recent research has moved to how EO affects other measures of performance such as environmental performance and GCA. Second, theoretical studies on the indirect role that GI plays in the relationship between EO and GCA are scarce. Extant studies have primarily focused on the direct relationship between EO and financial performance. This study will contribute to the research on EO and GCA with the goal of reducing the negative environmental footprint of hospitality firms and ensuring sustainable tourism. The study is organised as follows. First, the literature review and hypotheses development are done in Section 2. This is followed by the research methodology in Section 3, results in Section 4, discussion in Section 5, and conclusions in Section 6.

\section{Literature Review and Hypotheses Development}

\subsection{Theoretical Framework}

The stakeholder theory, the resource-based view, and the natural resource-based view provide the theoretical foundation for this study. The Stakeholder theory by [23] argues that there are interconnected relationships between a firm and its customers, employees, suppliers, investors, and communities and value should be created for all stakeholders. According to [8], the stakeholder theory is an avenue for internalising environmental cost from a firm's perspective, and the performance of the firm should not only be measured by economic performance but also social and environmental performance. The stakeholder perspective of corporate environmentalism recognises stakeholders' environmental concern and the strategic actions that are taken to improve the environmental performance of a firm. In addition, the link between EO and GCA can be explained by the natural resource-based view (NRBV) [24]. The NRBV builds upon the RBV by [25] and proposes that the competitive advantage of a firm is derived from its relationship with the natural environment. The 
theory argues that advantage is obtained on the basis of three interconnected strategies, which are product stewardship, pollution prevention, and sustainable development.

\subsection{Environmental Orientation (EO)}

Banerjee [8], in a seminal paper on corporate environmentalism, describes EO as a concept of corporate responsibility towards the environment. EO recognises the effect that a firm has on the environment and the need to minimise the effect. EO is a corporate value that is similar to corporate social responsibility as it involves the respect and care that a firm has for the environment and responding to the needs of external stakeholders [8]. EO shows the extent to which a firm incorporates environmental issues into its strategy with the goal of reducing the harmful impact of its activities on the natural environment [26]. EO can be divided into two parts: internal and external. Internal environmental orientation (IEO) focuses on a firm's internal values, standards of ethical behaviour, and its commitment to protect the environment. IEO is often revealed by the environmental mission statements in the annual reports of firms and environmental activities of employees and management [26]. The development of a corporate sustainability initiatives and culture begins with a mission statement that considers financial, social, and environmental performance. Therefore, a firm's mission statement helps to communicate its corporate orientation to diverse stakeholders [27]. In addition, IEO reflects a high level of commitment to environmentalism by employees and the management of a hospitality firm. Many hotels have top management that is personally involved and committed to environmentalism. Such involvement helps hotels set environmental goals and create incentives to employees for improved environmental performance [28].

External environmental orientation (EEO) depicts a manager's perception of external stakeholders and the importance of responding to stakeholders' environmental interests $[9,29]$. These stakeholders may impose pressures through norms or formal pressure through regulations on the firm. EEO is informed by a firm's responsibility towards society, the need to ensure sustainable development, the need to protect the environment for future generations, and the need for a positive firm image [10]. External stakeholders put pressure on firms to be liable for the natural environment and take actions to protect the environment. A firm's ability to meet its environmental responsibility especially to external stakeholders is dependent on the level of its EEO [9,30]. A firm with a low EEO would have a lower ability to proactively respond to external environmentalism compared to a firm with a high level of EEO [11,31]. A very important external stakeholder for the hospitality industry is the customer. Due to growing awareness of customers about environmental issues and the importance of environmental preservation, many hospitality firms have developed green practices as a response to the environmental concerns of customers [32]. Therefore, hospitality firms with a high level of EO are able to meet the environmental demands of customers. Sustainable external orientation and practices give firms in the hospitality sector a better reputation with customers. There is a positive association between environmental practices and performance in the hospitality sector [33].

\subsection{Green Innovation (GI)}

Innovation can be described as the process through which a firm transforms ideas into new products, services, or processes that can help the firm compete in the marketplace [34]. It is estimated that the global greenhouse gas (GHG) emissions will increase by $70 \%$ by 2050. Other environmental challenges faced by the world include the availability of water, maintenance of biodiversity, and dealing with the disposal of toxic substances and solid waste. Innovation, especially green innovation, has a major role to play in green growth [35]. The tourism industry faces a range of important sustainability challenges. However, the tourism industry is also faced by growing pressure from consumers and government on the need to improve sustainability and contribute positively to climate change. The hospitality sector needs to develop environmentally friendly production processes, organisational methods, and good and services that will reduce the reduction of the consumption of water, 
energy, and other materials $[35,36]$. Green innovation is of importance to sustainability and maximising the social, cultural, and environmental benefits of tourism in the transition to a green economy [37].

GI depicts all aspects of innovation that focus on energy conservation, waste recycling, pollution prevention, waste reduction, green product design, and an environmental management system [21,22]. According to [38], GI are innovations that can help a firm save energy, prevent pollution, recycle waste, and optimise the use of natural resources. The other terms used for GI include environmental innovation, ecological innovation, and sustainable innovation [39]. One of the ways for the firms in the hospitality industry to improve their green innovation is through green open innovation activities. Green open innovation can be described as the process whereby firms use a combination of internal research and external knowledge of sustainability to create innovations. Thus, green innovation is a collaborative relationship between a hospitality firm, its internal partners (employees) and management, and external partners (customers, suppliers, and government). This allows hospitality firms to integrate inside and outside knowledge with their business partners [40,41]. Green innovation in the hospitality industry focuses on the reduction of energy use, the implementation of solar powered technologies, and the use of more-efficient heating systems and the minimisation of solid waste generation. It also involves employees' participation in the development of sustainable ideas and action and the sharing of knowledge amongst the employees of the hotel. Green innovation also includes green marketing to improve the hotels' green image and attract green customers. The benefits of green innovation to hotels include cost reduction, environmental accreditations, and improved image and reputation [12].

\subsection{Green Competitive Advantage (GCA)}

Competitive advantage refers to the situation whereby a firm has a superior position in the marketplace. This enables the firm to outperform its competitors [42]. Banerjee [8] argues that the RBV (Barney, 1991) attempts to explain sustainability in an economic rather than social or environmental way and that the sustained competitive advantage depends on a firm's extant resource base. To achieve competitive advantage, a hotel must create and sustain positive values that are equal to or exceed those of rivals [43]. A hospitality firm's ability to establish competitive advantage lies in customer satisfaction and retention and its ability to promote itself as a responsible corporate citizen is a major differentiate strategy. Therefore, there is the need for hospitality firms to integrate environmental issues into corporate strategy to achieve competitive advantage [28]. Chen and Chang [44] define GCA as a situation under which a firm occupies some positions about environmental management that are hard for competitors to copy. GCA is a condition under which firms gain sustainable benefits from successful environmental strategies [45]. Astuti and Datrini [17] describe GCA as a situation in which a firm occupies certain positions regarding environmental protection that rivals find difficult to imitate. Hospitality firms that create environmental innovation can gain competitive advantage through a better company environmental image, retention of existing customers and attraction of new customers, increased market share, and improved performance [28,45].

\subsection{Environmental Orientation and Green Innovation}

Zehir and Ozgul [10] investigate the effect of IEO and EEO on GI based on a dataset of 253 manufacturing firms in China. The findings show that both IEO and EEO positively impact on green product innovation. Deluca et al. [11], in a study that focused on first and second ISO 500 Industrial Enterprises in Turkey, find that both IEO and EEO positively affect green innovation. Zameer et al. [46], in a study that focused on manufacturing firms in China, find that EO positively impacts on green innovation. Reyes-Santiago and Díaz-Pichardo. [12] examine the relationship between a proactive environmental strategy and the eco-innovation of hotels in Mexico. Based on a dataset of 126 firms, the study finds that a proactive environmental strategy is positively related to the green innovation of 
hotels. IEO supports green innovation because it enables a firm to take into consideration the interests of internal stakeholders, especially employees in innovative activities [47]. In addition, EEO depicts the need to respond to the concerns of various external stakeholders on environmental issues by firm management. These external stakeholders include the government, which can impose regulations, and customers, who can decide not to buy a product or service that fails to take into consideration the environment [47]. Therefore, organisations may implement green innovation to improve legitimacy with both internal and external stakeholders with respect to environmental issues $[10,11]$. Consequently, the following are hypothesised:

Hypothesis 1. IEO and GI are significantly positively related.

Hypothesis 2. EEO and GI are significantly positively related.

\subsection{Environmental Orientation (EO and Green Competitive Advantage (GCA)}

Reyes-Santiago and Díaz-Pichardo [12] find that a proactive environmental strategy is positively related to the organisational and environmental performance of hotels in Mexico. The authors of [48] investigate the effect of an environmental management system (EMS) on the perception of competitive advantage of firms. The findings indicate that firms with EMS exhibit significant differences in cost leadership and differentiation strategy compared to firms without EMS. Firms with EMS are able to derive significantly better operational efficiencies and greater supply chain optimisation compared to firms without EMS. Atkin and Newton [48] find that firms with environmental concern, environmental conservation policies, and environmental stewardship responsibilities are able to improve their competitive advantage. EO can lead to the creation of green products that are difficult to imitate by competitors, leading to sustainable benefits [16]. IEO focuses on a firms internal values, ethical standards, and commitment to protect the environment. This can lead to the development of green products and services that are difficult to imitate and improve a firm's green competitive advantage. In addition, EEO focuses on how a firm fulfils the expectations of external stakeholders on environmental issues [49]. This can lead to the development of green products that are difficult to imitate but meet the green expectation of customers. Consequently, the following are hypothesised:

Hypothesis 3. IEO and GCA are significantly positively related.

Hypothesis 4. EEO and GCA are significantly positively related.

\subsection{Green Innovation (GI) and Green Competitive Advantage (GCA)}

Chatzoglou and Chatzoudes [50], in a Greek study, find that innovation positively affects competitive advantage. Innovation leads to the creation and introduction of new products and services that deliver superior value to the customers of a firm. Innovation enables the firm to attract new customers, retain existing customers, secure market-leading positions, and obtain competitive advantage [51]. Reyes-Santiago and Díaz-Pichardo [12] find that the effect of green innovation on organisational performance of hotels is negative and significant. However, the study also finds a significant positive relationship between green innovation and environmental performance. Zameer et al. [46] point out that green innovation enables a firm to save costs, improve the efficiency of its operation, obtain a green reputation, and finally improve its green competitive advantage. The following is hypothesised:

Hypothesis 5. GI and GCA are significantly positively related. 


\subsection{Mediating Role of GI in the Relationship between(E) and GCA}

Lee and Yoo [52] argue that existing research has evaluated how EO affects firm performance, but there is little understanding of the organisational mechanisms that link such strategy to competitive advantage. There is a lack of clarity on how environmental strategies relate to organisational strategies that lead to competitive advantage. Astuti and Datrini [17] find that environmental innovation mediates the relationship between environmental pressure forces and firm performance in Jordan. Delmas et al. [53] investigate the relationship between environmental ethics and firm competitive advantage through the mediating role of GI in manufacturing firms in Taiwan. The results show that GI plays an indirect role in the relationship between firm environmental ethics and competitive advantage. Deluca et al. [11] find that the mediating effects of green innovation in the relationship between IEO and EEO and firm financial performance is significant. This suggests that GI is a mechanism through which both IEO and EEO can affect a firm's GCA. This study proposes the following hypotheses:

Hypothesis 6. GI mediates the relationship between IEO and GCA.

Hypothesis 7. GI mediates the relationship between EEO and GCA.

Figure 1 depicts the conceptual model of the study.

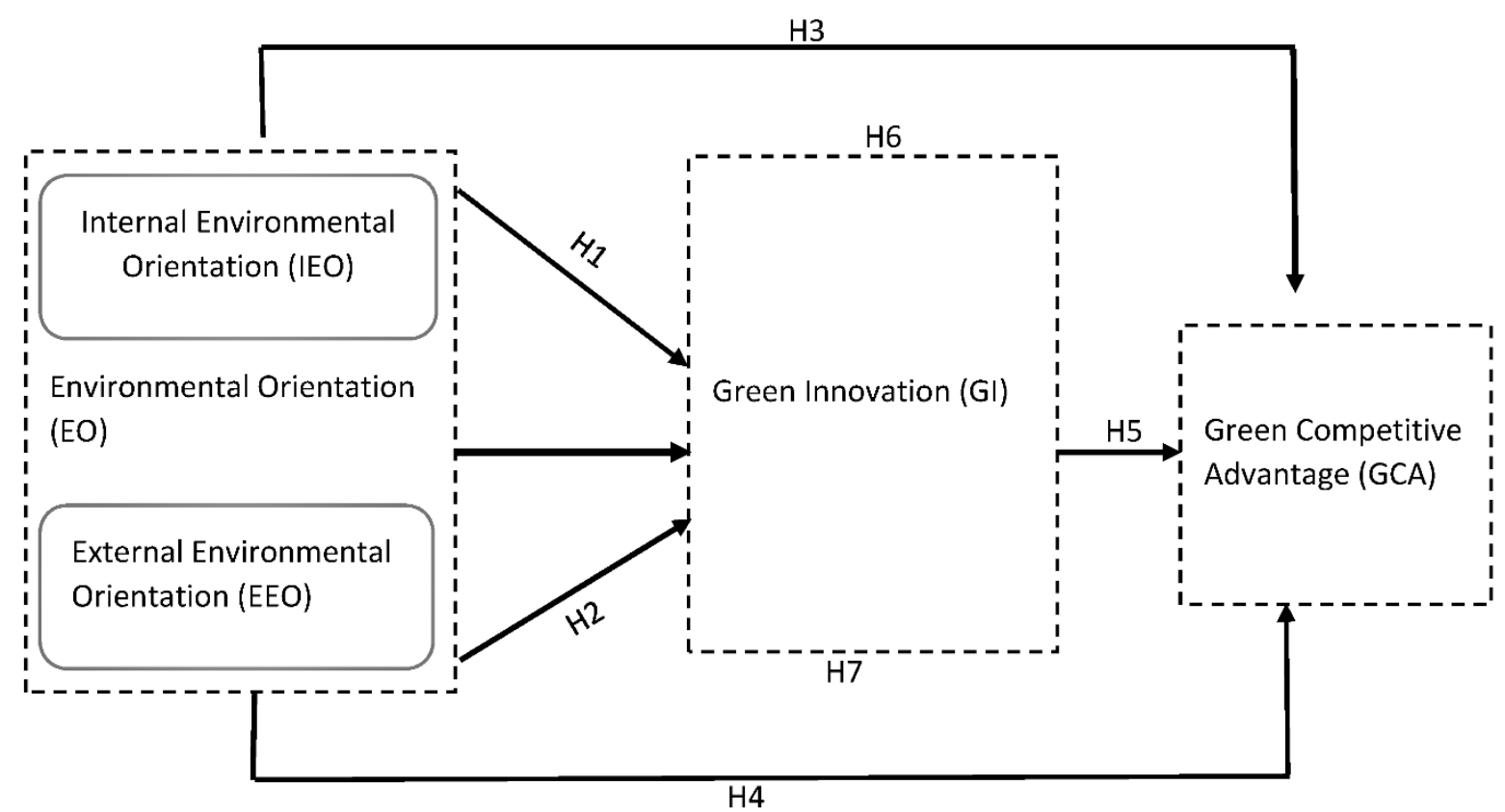

Figure 1. Conceptual model.

\section{Material and Methods}

The cross-sectional survey method was used to collect data from the respondents in a quantitative study. The survey focused on hotel managers who are expected to know the environmental strategy and performance of their firms. The researcher developed the list of the hotels that participated in the survey using the Tourism Grading Council of South Africa. The simple random sampling method was used to select hotels graded as three, four, and five star by the Tourism Grading Council of South Africa. Upscale hotels are more likely to be engaged in environmental practices compared to small hotels. The study area included Pretoria and Johannesburg. The two cities are located in the Gauteng Province. In addition, two cities (Polokwane and Bela-Bela) located in the Limpopo Province were included in the survey. The four cities have a sizeable number of hotels. The researcher contacted the management of the selected hotel through phone calls and emails to request 
for their participation in the survey. Afterwards, the questionnaire depicting the purpose of the study and a covering letter were sent to the manager of the hotels that agreed to participate in the survey. Three trained field agents assisted in the data collection process from participating hotels using the self-administered questionnaire method. The emails and phone numbers of the participants were obtained during questionnaire distribution, and reminders were sent weekly to request for the completion of questionnaire. If a questionnaire was not completed after two months, it was regarded as a non-response. The questionnaire contained a cover letter that explained the aim of the study and anonymity and confidentiality. The questionnaire was examined by two experts in the area of sustainability and strategy. In addition, the questionnaire was pretested in order to improve the face and content validity. The actual survey was done between July 2020 and February 2021. The questionnaire has four sections. These are (1) demographic variables, (2) EO, (3) GI, and (4) GCA. The study adopted the Partial Least Square Structural Equation modelling for analysis.

Measures:

EO was divided into IEO and EEO, and both constructs were measured by four questions, each adopted from [9]. The questions were based on the five-point Likert scale with $1=$ "Strongly disagree" and $5=$ "Strongly agree".

Green innovation (GI): Seven questions adopted from $[22,53,54]$ were used to measure GI. The questions were based on the five-point Likert scale with $1=$ "Strongly disagree" and $5=$ "Strongly agree".

Green competitive advantage (GCA): Four questions adopted from [44,55] were used to measure GCA. The questions were based on the five-point Likert scale with $1=$ "Strongly disagree" and $5=$ "Strongly agree".

The full measures of the three constructs are shown in Table A1

\section{Results}

\subsection{Response Rate and Biographical Characteristics}

A total of 500 questionnaires were distributed in the actual survey, and 190 usable questionnaires were returned. The "rule of ten" was used to decide the sample size of the study. In this study, there are 19 question items (Appendix A), so a minimum of 190 respondents will be needed.

As depicted by Table 1, the majority of the respondents were male with post-matric qualification and in the 41-50 age group. In addition, the hotels that participated in the survey had a three-star grading and have been in existence for between six and ten years.

\subsection{Evaluation of PLS SEM}

The valuation of PLS SEM includes the measurement and structural models.

\subsubsection{Measurement Model}

Hair et al. [56] remark that the assessment of the measurement model should comprise of the following factors. First, the factor loading should be greater than 0.78 . The composite reliability should be greater than 0.790 . Cronbach's alpha should be above 0.700 , and the Average Variance Extracted should be greater than 0.500. Table 2 shows that all the requirements highlighted by [56] Hair et al. (2019) have been satisfied. In addition, Table 3 shows that the AVE of each construct has a square root that is greater than the correlation coefficients of the constructs. 
Table 1. Biographical details of the respondents.

\begin{tabular}{|c|c|c|}
\hline Biographical Details of the Respondents & Frequency $(\mathrm{N}=190)$ & Percentage \\
\hline \multicolumn{3}{|l|}{ Level of education of the respondents } \\
\hline Matric & 18 & 9.5 \\
\hline Post Matric & 172 & 90.5 \\
\hline \multicolumn{3}{|l|}{ Gender of the respondents } \\
\hline Male & 116 & 61.0 \\
\hline Female & 74 & 39.0 \\
\hline \multicolumn{3}{|l|}{ Age of the respondents } \\
\hline Less than 20 & 0 & 0 \\
\hline 20-30 years & 6 & 3.2 \\
\hline $31-40$ years & 58 & 30.5 \\
\hline $41-50$ years & 77 & 40.5 \\
\hline $51-60$ years & 53 & 25.8 \\
\hline \multicolumn{3}{|l|}{ Age of the firm } \\
\hline Less than one year & 0 & 0 \\
\hline $1-5$ years & 36 & 19.0 \\
\hline 6-10 years & 104 & 54.7 \\
\hline Above ten years & 52 & 26.3 \\
\hline \multicolumn{3}{|l|}{ Type of hotel } \\
\hline 3-star & 107 & 56.3 \\
\hline 4-Star & 53 & 27.9 \\
\hline 5-Star & 29 & 15.8 \\
\hline
\end{tabular}

Table 2. The measurement model.

\begin{tabular}{|c|c|c|c|c|c|c|}
\hline Constructs & Items & $\begin{array}{c}\text { Mean and Standard } \\
\text { Deviation }\end{array}$ & Factor Loading & $\begin{array}{c}\text { Cronbach's } \\
\text { Alpha }\end{array}$ & $\begin{array}{l}\text { Composite } \\
\text { Reliability }\end{array}$ & AVE \\
\hline $\begin{array}{l}\text { Internal Environmental } \\
\text { Orientation (IEO) }\end{array}$ & & $\begin{array}{l}4.25 \\
1.03\end{array}$ & & 0.819 & 0.875 & 0.637 \\
\hline & $\begin{array}{l}\text { IEO1 } \\
\text { IEO2 } \\
\text { IEO3 } \\
\text { IEO4 }\end{array}$ & & $\begin{array}{l}0.816 \\
0.737 \\
0.808 \\
0.829\end{array}$ & & & \\
\hline $\begin{array}{l}\text { External Environmental } \\
\text { Orientation (EEO) }\end{array}$ & & $\begin{array}{l}3.62 \\
1.01\end{array}$ & & 0.771 & 0.895 & 0.682 \\
\hline 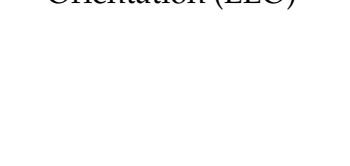 & $\begin{array}{l}\text { EEO1 } \\
\text { EEO2 } \\
\text { EEO3 } \\
\text { EEO4 }\end{array}$ & 1.01 & $\begin{array}{l}0.758 \\
0.901 \\
0.836 \\
0.801\end{array}$ & & & \\
\hline Green Innovation (GI) & & $\begin{array}{l}3.28 \\
1.04\end{array}$ & & 0.744 & 0.917 & 0.611 \\
\hline & $\begin{array}{l}\text { GI1 } \\
\text { G12 } \\
\text { G13 } \\
\text { GI4 } \\
\text { GI5 } \\
\text { GI6 } \\
\text { GI7 }\end{array}$ & & $\begin{array}{l}0.806 \\
0.803 \\
0.744 \\
0.817 \\
0.729 \\
0.769 \\
0.800\end{array}$ & & & \\
\hline $\begin{array}{l}\text { Green competitive } \\
\text { advantage }\end{array}$ & & $\begin{array}{l}3.22 \\
1.02\end{array}$ & & & & \\
\hline & $\begin{array}{l}\text { GCA1 } \\
\text { GCA2 } \\
\text { GCA3 } \\
\text { GCA4 }\end{array}$ & & $\begin{array}{l}0.841 \\
0.738 \\
0.809 \\
0.730\end{array}$ & 0.800 & 0,862 & 0.608 \\
\hline
\end{tabular}


Table 3. Discriminant validity.

\begin{tabular}{lllll}
\hline Construct & IEO & EEO & GI & GCA \\
\hline IEO & $\mathbf{0 . 7 9 8}$ & & & \\
EEO & 0.604 & $\mathbf{0 . 8 2 6}$ & & \\
GI & 0.517 & 0.602 & $\mathbf{0 . 7 8 2}$ & $\mathbf{0 . 7 8 0}$ \\
GCA & 0.482 & 0.549 & $\mathbf{0 . 5 9 9}$ & \\
\hline
\end{tabular}

Note: Diagonals depicted in bold depict the square root of the AVE, and other figures show the correlations.

\subsubsection{Structural Model}

The appraisal of the structural model should include (1) the common method bias (CMB) (2), the goodness of fit, (3) the $\mathrm{R}^{2}$, (4) the $\mathrm{Q}^{2}$, and (5) the effect size [56] (Hair et al., 2019). To test the existence of $C M B$, the variance inflation factors below 3.3 for the constructs shows that CMB is not present. The $\mathrm{R}^{2}$ value is 0.52 , and according to [57], this can be regarded as moderate. The value of the GOF is 0.574 , and this shows the strong predictive power of the model. The effect size values are moderate, and the standardised root mean square residual (SRMR) value of 0.02 depicts a good model fit. Table 4 depicts the summary of the results of the structural model.

Table 4. Path coefficient and T-statistics.

\begin{tabular}{cccc}
\hline Hypothesised Path & Path Coefficient & T-Statistics & Decision \\
\hline H1 IEO $\rightarrow$ GI & 0.392 & $5.408^{*}$ & Supported \\
H2 EEO $\rightarrow$ GI & 0.208 & $5.208^{* *}$ & Supported \\
H3 IEO-GCA & 0.198 & $4.428^{*}$ & Supported \\
H4 EEO-GCA & 0.181 & $3.002^{*}$ & Supported \\
H5 GI-GCA & 0.207 & $4.558^{* *}$ & Supported \\
${ }^{*} p<0.01 ; * * 0.05$. & &
\end{tabular}

Table 4 shows that both IEO and GI are significantly positively related in support of hypotheses one and two. In addition, both IEO and EEO and GCA are significantly positively related in support of hypotheses three and four. GI and GCA are significantly positively related in support of hypothesis five as well.

Table 5 shows the results of mediation. The indirect paths are positive and significant. In addition, the Variance Accounted For (VAR) values are less than $80 \%$, indicating a complementary partial mediation $[56,58]$. Thus, hypotheses six and seven are supported.

Table 5. Mediation results.

\begin{tabular}{|c|c|c|c|c|c|}
\hline Mediation Path & $\begin{array}{l}\text { Indirect } \\
\text { Effect }\end{array}$ & $\begin{array}{l}\text { Total Effect and } \\
\text { T-Statistics }\end{array}$ & $\begin{array}{l}\text { Confidence Interval } \\
\text { Bias (Corrected) }\end{array}$ & Decision & VAF \\
\hline & & & $\begin{array}{l}\text { LL } \\
\mathrm{UL}\end{array}$ & & \\
\hline $\mathrm{H} 6 \mathrm{IEO} \rightarrow \mathrm{GI} \rightarrow \mathrm{GCA}$ & $0.146^{*}$ & $\begin{array}{l}0.344^{*} \\
(1.241)\end{array}$ & $\begin{array}{l}0.069 \\
0.248\end{array}$ & $\begin{array}{l}\text { Accepted (partial } \\
\text { mediation) }\end{array}$ & $42.44 \%$ \\
\hline $\mathrm{H} 7 \mathrm{EEO} \rightarrow \mathrm{GI} \rightarrow \mathrm{GCA}$ & $0.133^{* *}$ & $\begin{array}{l}0.314^{* *} \\
(1.108)\end{array}$ & $\begin{array}{l}0.058 \\
0.162\end{array}$ & $\begin{array}{l}\text { Accepted (partial } \\
\text { mediation) }\end{array}$ & $42.35 \%$ \\
\hline
\end{tabular}

\section{Discussion}

The tourism industry including the hospitality sector makes a significant contribution to the South African economy. In 2018, tourism indirectly contributed $8.2 \%$ of the gross domestic product of South Africa. In addition, the contribution of tourism to employment was $9.2 \%$ [59]. However, tourism also puts considerable pressure on the environment. This can be attributed to the industry's excessive consumption of resources such as energy and 
water [60]. However, the industry can also can also enhance environmental preservation through their operation and strategy [28].

The study investigated the effect of EO (as measured by IEO and EEO) on the GCA. In addition, the study examined the mediating effect of GI in the relationship between EO and GCA. The results indicated that IEO and EEO and GI are significantly positively related, which supports hypotheses one and two. The findings suggest that having an environmental orientation strategy enables a firm to focus on innovation that will lead to energy conservation, waste reduction, and recycling and pollution, which is in line with prior studies. The authors of [10] find that both internal and external environmental orientation positively impact on green innovation. The findings of the study [10] indicated that internal and external environmental orientation positively impacts on green innovation. Zameer et al. [46] also found that environmental orientation (measured unidimensionally) positively impacts on green innovation. The findings of the study indicate that IEO and EEO and GCA are significantly positively related in support of hypotheses three and four. The findings suggest that firms can improve their green competitive strategy by adopting an environmental orientation strategy. Previous empirical studies reached similar empirical conclusions. Atkin and Newton [48] found that firms with EMS exhibit significant differences in cost leadership and differentiation strategy compared to firms without EMS. Firms with EMS are able to derive significantly better operational efficiencies and greater supply chain optimisation compared to firms without EMS. The findings of the study by [49] indicated that firms with environmental concern, environmental conservation policies, and environmental stewardship responsibilities are able to improve their competitive advantage. The findings indicate that GI and GCA are positively related in support of hypothesis five. The findings suggest that GI enables a firm to save costs, improve the efficiency of its operation, obtain green reputation, and finally improve green competitive advantage. The authors of [51] found that innovation positively affects competitive advantage. Innovation enables the firm to attract new customers, retain existing customers, secure market-leading positions, and obtain competitive advantage. Zameer et al. [46] remarked that green innovation enables a firm to obtain cost savings, improve efficiency, obtain a green reputation, and ultimately enhance green competitive advantage. The findings confirm the mediating effects of GI in the relationship between IEO and GCA and EEO and GCA in support of hypotheses six and seven. The findings suggest that GI is a mechanism through which both EO can affect GCA. The findings are consistent with previous empirical studies on the mediating effect of GI. Eiadat et al. [21] found that environmental innovation mediates the relationship between environmental pressure forces and firm performance in Jordan. The findings of the study by [54] indicated that green innovation has an indirect effect on the relationship between firm environmental ethics and competitive advantage. The findings of the study by [61,62] supported the role of GI as a mediator in the link between IO and $\mathrm{EO}$ and firm financial performance.

\section{Conclusions}

The study examined if EO (as measured by IEO and EEO) and the GCA of hospitality firms are significantly positively related. In addition, the study investigated whether GI mediates the relationship EO and GCA. The findings of the study showed that EO and GI and GC are significantly positively related. In addition, GI mediates the relationship between EO and GCA. The findings can be linked to the stakeholder theory and the natural resource-based view (NRBV). A firm should take into consideration the interest of various stakeholders. An environmental orientation strategy takes into consideration a firm's relationship with its environment. In addition, according to the NRBV, a firm can derive competitive advantage on the basis of its environmental strategy and its relationship with the natural environment. The study developed a theoretical model that depicts GI as a mechanism through which EO can affect GCA. Empirically, the study contributes to the literature on the effect environmental strategy on the competitive advantage of hospitality firms. The study has the following managerial implications. First, the findings of the 
study shows that EO is a driver of GCA. Although environmental initiatives often come with costs and risk, the findings show that an environmental strategy can positively affect the competitive advantage of hospitality firms. It is important for the management of hospitality firms to develop an environmental strategy in order to obtain GCA. There is the need for the management of hospitality firms to provide workshops and training on environmental strategy for the management and employees of hospitality. The reward and promotion of managers and employees of hospitality firms should include the achievement of environmental goals. One of the findings of the study is the indirect effect of GI. Therefore, hospitality firms must focus on GI that focuses on energy conservation, waste recycling, pollution prevention, waste reduction, green product design, and an environmental management system in order to gain green competitive advantage. It is important for the management of hospitality firms to provide training on GI to employees. It is important for the management of hospitality firms to create an environment that supports green innovation by employees. The study has the following limitations and suggests some new study areas. First, the cross-sectional nature of the survey limits the ability to discern cause-and-effect relationships, and a longitudinal study will help to improve the results. Second, the survey was done on firms in one industry and one country. To improve the generalisability of the findings, further studies can include other industries in other countries. In addition, other studies can examine if environmental dynamism can play an indirect role in the link between GI and GCA of hospitality firms. The link between green organisational culture and the EO and GCA of hospitality firms can also be examined. Furthermore, the impact of $\mathrm{EO}$ on the triple bottom line performance measures (financial, social, and environmental) of hospitality firms can be examined by other studies. A subgroup analysis of how environmental orientation can affect performance in three, four, and five-star hotels in different areas of South Africa can be investigated by other studies.

Funding: The study was funded by the Department of Business Management, University of Limpopo Grant BMAN/05/20.

Institutional Review Board Statement: Not applicable.

Informed Consent Statement: Not applicable.

Data Availability Statement: Not applicable.

Conflicts of Interest: The author declares no conflict of interest. The funders had no role in the design of the study; in the collection, analyses, or interpretation of data; in the writing of the manuscript, or in the decision to publish the results.

\section{Appendix A}

Table A1. Questionnaire.

\begin{tabular}{|c|c|c|c|}
\hline Construct & Items & Source & Response Category \\
\hline $\begin{array}{c}\text { Internal } \\
\text { environmental } \\
\text { orientation (IEO) }\end{array}$ & $\begin{array}{l}\text { 1. At our firm, we make a concerted effort to make } \\
\text { every employee understand the importance of } \\
\text { environmental preservation. }\end{array}$ & [9] & $\begin{array}{c}\text { Five-point Likert } \\
\text { scales }(1=\text { Strongly } \\
\text { Disagree; } 5=\text { Strongly } \\
\text { Agree })\end{array}$ \\
\hline
\end{tabular}


Table A1. Cont.

\begin{tabular}{|c|c|c|c|}
\hline Construct & Items & Source & Response Category \\
\hline $\begin{array}{c}\text { External } \\
\text { environmental } \\
\text { orientation (EEO) }\end{array}$ & $\begin{array}{l}\text { 1. The financial well-being of our firm does not } \\
\text { depend on the state of the natural environment. } \\
\text { (reverse-scored) } \\
\text { 2. Our firm has a responsibility to preserve the } \\
\text { environment. } \\
\text { 3. Environmental preservation is vital to our firm's } \\
\text { survival. } \\
\text { 4. Our firm's responsibility to its customers, } \\
\text { stockholders, and employees is more important than } \\
\text { our responsibility toward environmental } \\
\text { preservation. (reverse-scored) }\end{array}$ & [9] & $\begin{array}{c}\text { Five-point Likert } \\
\text { scales }(1=\text { Strongly } \\
\text { Disagree; } 5=\text { Strongly } \\
\text { Agree })\end{array}$ \\
\hline
\end{tabular}

1. Our firm has improved environmentally friendly packaging for new and existing products/services.

2. Our firm uses environmental considerations in developing products and services.

3. Our firm uses technology to make energy and water savings and reduce pollution.

Green innovation 4. Our firm uses low energy and water in the process (GI) of providing services to customers.

5. Our firm uses recycled and reused material in the process of providing services to customers.

Five-point Likert scales $(1=$ Strongly Disagree; 5 = Strongly Agree)

6. Our firm uses less material in the in the process of providing services to customers.

7. Our firm has reduced pollution and emission of hazardous substances in the in the process of providing services to customers.

1. Our firm has competitive advantage of low cost in the area of environmental management or green innovation compared to its major competitors.

2. The quality of the green products or services that

Green competitive advantage (GCA) our firm offers is better than that of our major competitors.

3. Our firm is more capable of investing in environmental development and green innovation compared to its major competitors.

4. Our firm is more capable of environmental management compared to its major competitors.

\section{References}

1. Robertson, J.L.; Barling, J. Toward a new measure of organizational environmental citizenship behaviour. J. Bus. Res. 2017, 75, 57-66. [CrossRef]

2. Ferreira, L.; Barbi, F. The challenge of global environmental change in the anthropocene: An analysis of Brazil and China. Chinese Pol. Sci. Rev. 2016, 1, 685-697. [CrossRef]

3. Singh, R.L.; Singh, P.K. Global environmental problems. In Principles and Applications of Environmental Biotechnology for a Sustainable Future; Springer: Berlin/Heidelberg, Germany, 2017; pp. 13-41.

4. United Nations World Tourism Organisation. Tourism and Sustainable Development. Available online: https://www.unwto. org/sustainable-development (accessed on 5 January 2021).

5. Rosa, F.S.; Silva, L.C. Environmental sustainability in hotels, theoretical and methodological contribution. Brazilian J. Tou. Res. 2017, 11, 39-60.

6. Alipour, H.; Safaeimanesh, F.; Soosan, A. Investigating sustainable practices in hotel industry-from employees' perspective: Evidence from a Mediterranean Island. Sustainability 2019, 11, 6556. [CrossRef]

7. Ones, D.S.; Dilchert, S. Employee green behaviors. In Managing Human Resources for Environmental Sustainability; Jackson, S.E., Ones, D.S., Dilchert, S., Eds.; Jossey-Bass/Wiley: Hoboken, NJ, USA, 2012; pp. 85-116.

8. Banerjee, S.B. Corporate environmentalism: The construct and its measurement. J. Bus. Res. 2002, 55, 177-191. [CrossRef] 
9. Feng, L.; Zhao, W.; Li, H.; Song, Y. The effect of environmental orientation on green innovation: Do political ties matter? Sustainability 2018, 10, 4674. [CrossRef]

10. Zehir, C.; Ozgul, B. Environmental orientation and firm performance. Int. J. Res. Bus. Soc. Sci. 2020, 9, 13-25. [CrossRef]

11. Deluca, H.; Wagner, M.; Block, J. Sustainability and environmental behaviour in family firms: A Longitudinal analysis of environment related activities, innovation and performance. Bus. Strategy Environ. 2018, 27, 152-172. [CrossRef]

12. Reyes-Santiago, P.; Díaz-Pichardo, P. The influence of environmental dynamic capabilities on or-ganizational and environmental performance of hotels: Evidence from Mexico. J. Clean. Prod. 2019, 227, 414-423. [CrossRef]

13. Wisker, Z.L.; Kwiatek, P. The effects of environmental orientation on firm performance and a mediating role of employee-based brand equity: A comparative study. Int. J. App. Bus. Int. Manag. 2018, 3, 1-11. [CrossRef]

14. Boiral, O.; Guillaumie, L.; Heras-Saizarbitoria, I.; Tene, C.V.T. Adoption and outcomes of ISO 14001: A systematic review. Int. J. Manag. Rev. 2017, 20, 411-432. [CrossRef]

15. Voinea, C.; Hoogenberg, B.; Fratostiteanu, C.; Hashmi, H.B.A. The relation between environmental management systems and environmental and financial performance in emerging economies. Sustainability 2020, 12, 5309. [CrossRef]

16. Chen, Y.S.; Chang, C.H. Towards green trust: The influences of green perceived quality, green perceived risk, and green satisfaction. Manag. Dec. 2013, 51, 63-82. [CrossRef]

17. Astuti, D.A.; Datrini, L.K. Green competitive advantage: Examining the role of environmental consciousness and green intellectual capital. Manag. Sci. Let. 2021, 11, 1141-1415. [CrossRef]

18. Dangelico, R.M. Being green and competitive: The impact of environmental actions and collaboration on firm performance. Bus. Strategy Environ. 2015, 24, 413430. [CrossRef]

19. Adamako, S.; Amankwah-Amoah, J.; Konadu, R.; Owusu-Agyei, S. Environmental sustainability orientation and performance of family and nonfamily firms. Bus. Strategy Environ. 2019, 28, 1250-1259. [CrossRef]

20. Aboelmaged, M. Direct and indirect effects of eco-innovation, environmental orientation and supplier collaboration on hotel performance: An empirical study. J. Clean Pro. 2018, 184, 537-549. [CrossRef]

21. Eiadat, Y.; Kelly, A.; Roche, F.; Eyadat, H. Green and competitive? An empirical test of the mediating role of environmental innovation strategy. J. World Bus. 2008, 43, 131-145. [CrossRef]

22. Soewarno, N.; Tjahjadi, B.; Fithrianti, F. Green innovation strategy and green innovation: The roles of green organizational identity and environmental organizational legitimacy. Manag. Dec. 2018, 57, 1-15. [CrossRef]

23. Freeman, R.E. Strategic Management: A Stakeholder Approach; Pitman: Boston, MA, USA, 1984.

24. Hart, S.L. A natural-resource-based view of the firm. Acad. Manag. Rev. 1995, 20, 986-1014. [CrossRef]

25. Barney, J. Firm resources and sustained competitive advantage. J. Manag. 1991, 17, 99-120. [CrossRef]

26. Yu, Y.; Huo, B. The impact of environmental orientation on supplier green management and financial performance: The moderating role of relational capital. J. Clean. Prod. 2018, 211, 628-639. [CrossRef]

27. Penco, L.; Profumo, G.; Tutore, I. Mission statements and the sustainability communication. Symphonya. Emerg. Issues Manag. 2019, 95-108. [CrossRef]

28. Reynolds, P. Hotel companies and corporate environmentalism. Tour. Manag. Stud. 2013, 9, 7-12.

29. Chan, Y.K.; He, H.; Chan, H.K.; Wang, Y.C. Environmental orientation and corporate performance: The mediation mechanism of green supply chain management and moderating effect of competitive intensity. Ind. Mark. Manag. 2012, 41, 621-630. [CrossRef]

30. Gupta, S.; Kumar, V. Sustainability as corporate culture of a brand for superior performance. J. World Bus. 2013, 48, 311-320. [CrossRef]

31. Bowen, F.; Aragon-Correa, J.A. Greenwashing in corporate environmentalism research and practice: The importance of what we say and do. Org. Environ. 2014, 27, 107-112. [CrossRef]

32. Moise, M.S.; Gil-Saura, I.; Šerić, M.; Molina, M.E.R. Influence of environmental practices on brand equity, satisfaction and word of mouth. J. Brand Manag. 2019, 26, 646-657. [CrossRef]

33. Oliveras-Villanueva, M.; Llach, J.; Perramon, J. Service quality in hospitality and the sustainability effect: Systematic literature review and future research agenda. Sustainability 2020, 12, 8152. [CrossRef]

34. Roper, S.; Love, J.H.; Bonner, K. Firms' knowledge search and local knowledge externalities in innovation performance. Res. Policy 2017, 46, 43-56. [CrossRef]

35. OECD. Green Innovation in Tourism Services; OECD Tourism Papers, 2013/01; OECD Publishing: Paris, France, 2013. [CrossRef]

36. Gürlek, M.; Tuna, M. Reinforcing competitive advantage through green organizational culture and green innovation. Serv. Ind. J. 2017, 38, 467-491. [CrossRef]

37. Schwark, N.; Tiberius, V.; Fabro, M. How will we dine? Prospective shifts in international haute cuisine and innovation beyond kitchen and plate. Foods 2020, 9, 1369. [CrossRef] [PubMed]

38. Leal-Millan, A.; Leal-Rodríguez, A.L.; Albort-Morant, G. Green innovation. In Encyclopedia of Creativity, Invention, Innovation and Entrepreneurship; Springer: Berlin/Heidelberg, Germany, 2018.

39. Schiederig, T.; Tietze, F.; Herstatt, C. Green innovation in technology and innovation management-An exploratory literature review. RED Manag. 2012, 42, 180-192. [CrossRef]

40. Chang, C.-H. Green Open Innovation Activities and Green Co-Innovation Performance in Taiwan's Manufacturing Sector. Int. J. Environ. Res. Public Health 2020, 17, 6677. [CrossRef] [PubMed] 
41. Martínez, F.J.S.; Avellaneda-Rivera, L.; Moreno, A.G. Open and green innovation in the hospitality industry. Environ. Eng. Manag. J. 2016, 15, 1481-1487. [CrossRef]

42. Porter, M.E. Creating and Sustaining Superior Performance; The Free Press: Toronto, ON, Canada, 1985.

43. Hossain, M.S.; Hussain, K.; Kannan, S.; Nair, S.K. Determinants of sustainable competitive advantage from resource-based view: Implications for hotel industry. Hosp. Tour. Insights 2021, 1-12. [CrossRef]

44. Chen, Y.S.; Chang, C.H. Enhance environmental commitments and green intangible assets toward green competitive ad-vantages: An analysis of structural equation modeling (SEM). Qual. Quant. 2011, 47, 1-15.

45. Chen, Y.-S.; Lai, S.-B.; Wen, C.-T. The influence of green innovation performance on corporate advantage in Taiwan. J. Bus. Ethic 2006, 67, 331-339. [CrossRef]

46. Zameer, H.; Wang, Y.; Yasmeen, H.; Mubarak, S. Green innovation as a mediator in the impact of business analytics and environmental orientation on green competitive advantage. Manag. Decis. 2020. in print. [CrossRef]

47. Huang, C.; Kung, F. Environmental consciousness and intellectual capital management: Evidence from Taiwan's manufac-turing industry. Manag. Dec. 2011, 49, 1405-1425. [CrossRef]

48. Atkin, T.A.G., Jr.; Newton, S.K. Environmental strategy: Does it lead to competitive advantage in the US wine industry? Int. J. Wine Bus. Res. 2012, 24, 115-133. [CrossRef]

49. Giantari, I.G.A.K.; Sukaatmadja, I.P.G. Effects of environmental orientation, green marketing mix and social capital on the competitive advantage of real estate developers in Bali. Prop. Manag. 2021, in press. [CrossRef]

50. Chatzoglou, P.; Chatzoudes, D. The role of innovation in building competitive advantages: An empirical investigation. Eur. J. Innov. Manag. 2018, 21, 44-69. [CrossRef]

51. Bu, X.; Dang, W.; Wang, J.; Liu, Q. Environmental orientation, green supply chain management, and firm performance: Empirical evidence from chinese small and medium-sized enterprises. Int. J. Environ. Res. Public Health 2020, 17, 1199. [CrossRef]

52. Lee, K.; Yoo, J. How does open innovation lead competitive advantage? A dynamic capability view perspective. PLoS ONE 2019, 14, e0223405. [CrossRef] [PubMed]

53. Delmas, M.; Hoffmann, V.H.; Kuss, M. Under the tip of the iceberg: Absorptive capacity, environmental strategy, and competitive advantage. Bus. Soc. 2011, 50, 116-154. [CrossRef]

54. Chang, C.-H. The influence of corporate environmental ethics on competitive advantage: The mediation role of green innovation. J. Bus. Ethic 2011, 104, 361-370. [CrossRef]

55. Ma, Y.; Yin, Q.; Pan, Y.; Cui, W. Green product innovation and firm performance: Assessing the moderating effect of nov-eltycentered and efficiency-centered business model design. Sustainability 2018, 10, 1843. [CrossRef]

56. Hair, J.F.; Risher, J.; Sarstedt, M.; Ringle, C.M. When to use and how to report the results of PLS-SEM. Eur. Bus. Rev. 2019, 31, 2-24. [CrossRef]

57. Henseler, J.; Hubona, G.S.; Ray, P.A. Using PLS path modeling in new technology research: Updated guidelines. Ind. Manag. Data Syst. 2016, 116, 2-20. [CrossRef]

58. Nitzl, C.; Roldan, J.; Cepeda-Carrion, G. Mediation analysis in partial least squares path modeling: Helping researchers discuss more sophisticated models. Ind. Manag. Data Syst. 2016, 16, 1849-1864. [CrossRef]

59. World Travel and Tourism Council. Economic Impact Reports. Available online: https://wttc.org/Research/Economic-Impact. (accessed on 10 February 2021).

60. Han, H.; Yoon, H.J. Hotel customers' environmentally responsible behavioural intention: Impact of key constructs on decision in green consumerism. Int. J. Hos. Manag. 2015, 45, 22-33. [CrossRef]

61. Xie, X.; Huo, J.; Zou, H. Green process innovation, green product innovation, and corporate financial performance: A content analysis method. J. Bus. Res. 2019, 101, 697-706. [CrossRef]

62. Lin, Y.-H.; Chen, Y.-S. Determinants of green competitive advantage: The roles of green knowledge sharing, green dynamic capabilities, and green service innovation. Qual. Quant. 2016, 51, 1663-1685. [CrossRef] 